\title{
Past dynamics of the Australian monsoon: precession, phase and links to the global monsoon concept
}

\author{
L. Beaufort ${ }^{1}$, S. van der Kaars ${ }^{2,3}$, F. C. Bassinot ${ }^{4}$, and V. Moron ${ }^{1,5}$ \\ ${ }^{1}$ CEREGE, CNRS-Universités Aix-Marseille, Aix en Provence, France \\ ${ }^{2}$ Centre for Palynology and Palaeoecology, School of Geography and Environmental Science, Monash University, Victoria, \\ 3800 , Australia \\ ${ }^{3}$ Institute for Biodiversity and Ecosystem Dynamics, University of Amsterdam, Science Park 904, 1098 XH, \\ Amsterdam, The Netherlands \\ ${ }^{4}$ LSCE, CEA-CNRS, Gif sur Yvette, France \\ ${ }^{5}$ IRI, Columbia University, New York, USA
}

Received: 19 May 2010 - Published in Clim. Past Discuss.: 1 June 2010

Revised: 11 October 2010 - Accepted: 18 October 2010 - Published: 22 October 2010

\begin{abstract}
Past variations in the dynamics of the Australian monsoon have been estimated from multi-proxy analysis of a core retrieved in the Eastern Banda Sea. Records of coccolith and pollen assemblages, spanning the last 150000 years, allow reconstruction of past primary production in the Banda Sea, summer moisture availability, and the length of the dry season in northern Australia and southeastern Indonesia. The amount of moisture available during the summer monsoon follows typical glacial/interglacial dynamics with a broad asymmetrical 100-kyr cycle. Primary production and length of the dry season appear to be closely related, given that they follow the precessional cycle with the same phase. This indicates their independence from ice-volume variations. The present inter-annual variability of both parameters is related to El Niño Southern Oscillation (ENSO), which modulates the Australian Winter Monsoon (AWM). The precessional pattern observed in the past dynamics of the AWM is found in ENSO and monsoon records of other regions. A marked shift in the monsoon intensity occurring during the mid Holocene during a period of constant ice volume, suggests that low latitude climatic variation precedes increases in global ice volume. This precessional pattern suggests that a common forcing mechanism underlies low latitude climate dynamics, acting specifically and synchronously on the different monsoon systems.
\end{abstract}

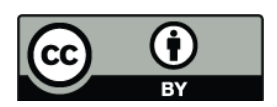

Correspondence to: L. Beaufort (beaufort@cerege.fr)

\section{Introduction}

The monsoons are seasonal wind reversals that occur generally over the tropics and are associated with precipitation changes. These reversals correspond to opposite summer and winter temperature gradients between continent and ocean and between both hemispheres. They lead to dry winters and wet summers. The Australian monsoon system is part of the Asian monsoon, but because it is not in the same hemisphere as Asia, the dry (wet) Australian winter (summer) monsoon is synchronous with the wet (dry) summer (winter) Asian monsoon. Although a link between both monsoon systems is apparent in modern climates (Trenberth et al., 2000), this relationship has not yet been well defined for past climates (Williams et al., 2009; Wang et al., 2005). The past dynamics of the Australian summer monsoon has been estimated through pollen analysis (Williams et al., 2009; Wang et al., 2005; Moss and Kershaw, 2000; Kershaw, 1974; Kershaw et al., 2007; van der Kaars et al., 2006; van der Kaars and Dam, 1995). However, the past intensity of the Australian winter monsoon is more difficult to estimate using palynological techniques because it is mostly characterized by wind intensity. The Banda Sea is located north of Australia and experiences strong seasonal changes in its primary production directly linked to the intensity of the winter monsoon (Moore et al., 2003). Coccolithophores are good markers of paleoproductivity (Beaufort et al., 1997). Here, we investigate the past variability of the Australian winter monsoon using coccolithophore analysis, and compare the results with a pollen-based reconstruction of summer monsoon humidity changes from the same core. The aim is to produce past

Published by Copernicus Publications on behalf of the European Geosciences Union. 


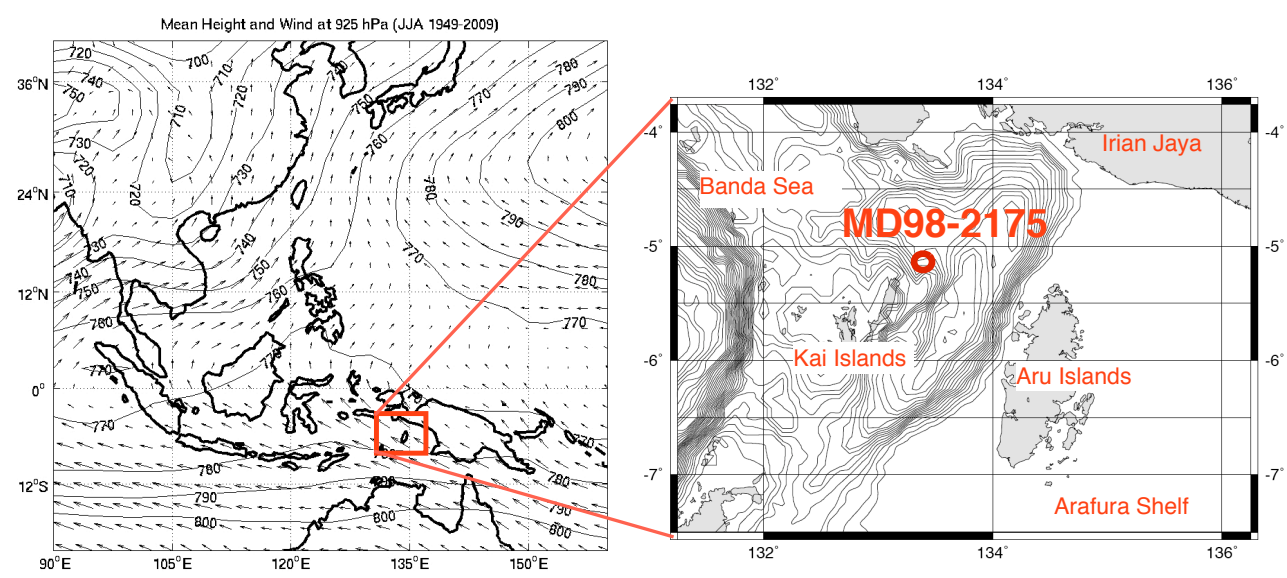

Fig. 1. Left: Map showing the mean wind fields (arrows) and geopotential height (m) for $925 \mathrm{hPa}$ from NCEP-1 for June, July and August between 1949 and 2009. Right: Map showing the location of core MD98-2175.

estimates of the dynamics of the Australian monsoon in both seasons and to compare the findings with the dynamics of the Asian monsoon system.

\section{Regional setting}

The climate over the eastern Banda Sea is dominated by the monsoon. During the austral winter (JJA), strong trade winds blow from the south-east. At the Equator, these southeast monsoon winds turn clockwise, blowing from the southwest towards southern Asia to form the South Asian Summer Monsoon (Fig. 1). In the Banda Sea, these austral winter winds produce an intense upwelling activity by Ekman pumping (Moore et al., 2003). Primary production (PP) reaches its peak between June and September, as shown by the monthly averaged, 1997-2010 SeaWif and MODIS remote sensing estimates of chlorophyll concentration between 4 and $5^{\circ} \mathrm{S}$ and 133 and $134^{\circ} \mathrm{E}$ (Fig. 2).

During the austral summer (DJF), the north-west monsoon brings moisture from the Indonesian archipelago and the Indian Ocean to Northern Australia. The strong atmospheric convection related to the southward migration of the InterTropical Convergence Zone (ITCZ) induces high precipitation over the Banda Sea, the Arafura shelf and Northern Australia. During that season, oligotrophic conditions prevail in the western Banda Sea (Fig. 2).

Satellite chlorophyll data reveal not only a strong seasonal contrast in productivity but also a large inter-annual variability (Fig. 2). The yearly-averaged primary production burst was strongly limited during the 1998 La Niña year (Moore et al., 2003), with an average chlorophyll concentration of $0.28 \mathrm{mg} \mathrm{m}^{-3}$, a level which is significantly reduced from that of the $0.41 \mathrm{mg} \mathrm{m}^{-3}$ yearly average. In contrast, during the 1997 El Niño year, the high PP season lasted until November when concentrations remained as high as $0.31 \mathrm{mg} \mathrm{m}^{-3}$
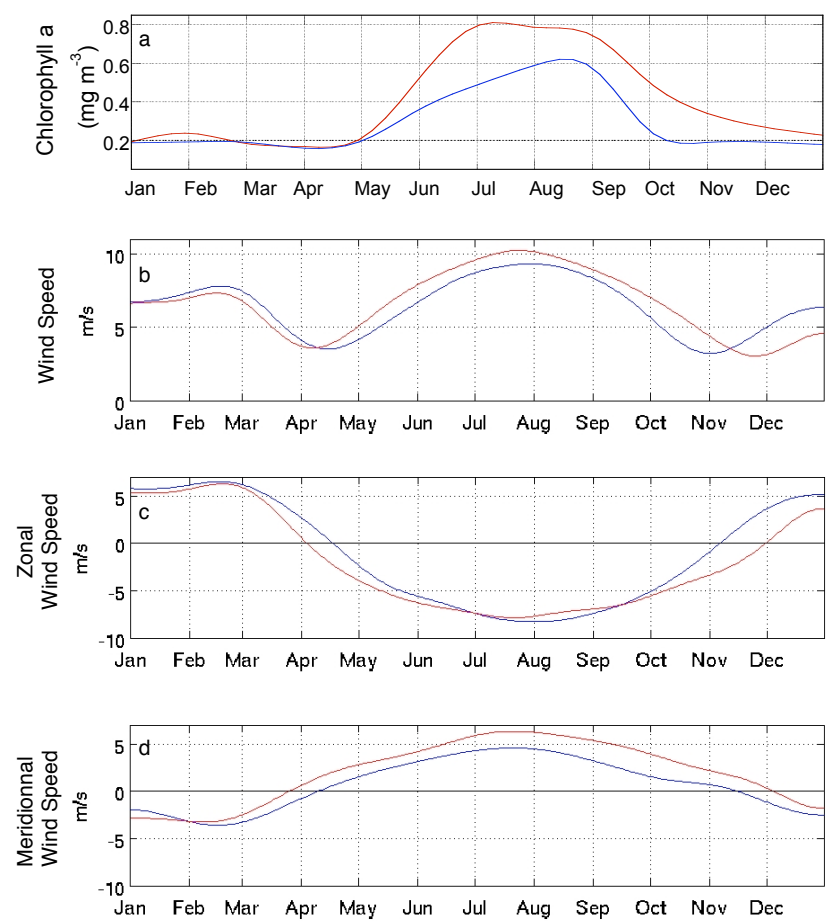

Fig. 2. (a) Satellite imagery estimates of monthly Chlorophyll a concentration in $\mathrm{mg}$ per cubic meter (left) from MODIS averaged on 5-6 ${ }^{\circ} \mathrm{S}$ and $133-134^{\circ} \mathrm{E}$ from 1997 to 2009 . In blue for years 1998, 1999, 2000 and 2007 (La Niña's), in red for years 2002, 2006 1997 and 2009 red dotted line) (El Niño events). Composites of JJA daily values (low-pass filtered) of a wind index (b: total; c: zonal; d: meridional speed) computed from NCEP-I averaged on $130^{\circ}$ $135^{\circ} \mathrm{E}, 7.5^{\circ} \mathrm{S}-2.5 \mathrm{~S}$ at $925 \mathrm{hPa}$ and for $10 \mathrm{El} \mathrm{Niño} \mathrm{(red)} \mathrm{and} 10 \mathrm{La}$ Niña (blue) years selected from Niño 3.4 data averaged on JJA. The JJA value of meridional winds are correlated at 0.54 with Niño 3.4 on 1948-2009 at -0.07 for zonal component and 0.31 for speed). 
(compared with usual levels of about $0.18 \mathrm{mg} \mathrm{m}^{-3}$ ). Moore et al. (2003) concluded that the El Niño Southern Oscillation (ENSO) largely controls the inter-annual primary production dynamics. Estimates of chlorophyll a concentrations in the quadrilateral $5-6^{\circ} \mathrm{S} / 133-134^{\circ} \mathrm{E}$ from 1997 to 2009 from MODIS remote sensing, indicate that, during El Niño years, the high PP season lasts longer and is more productive. This is consistent with the inter-annual wind variability estimated from NCEP-1 (National Center for Environmental Prediction) reanalysis, which shows that during El Niño years the strong wind season lasts about one month longer than in La Niña years (Fig. 2). However, during El Niño years the relative increase in PP is larger than that in wind intensity. This results from the change in the direction of the wind during El Niño events (more southerly), that changes the local divergence of surface winds (or curl of the wind), and enhances Ekman pumping during these events and therefore stronger upwelling. An increase in PP during El Niño years is contrary to the pattern observed in the eastern Pacific upwelling system (e.g. Philander, 1983). The fact that PP in the eastern Banda Sea reacts strongly to ENSO dynamics is to be expected because the Southern Oscillation Index is identified as the pressure difference between Tahiti and Darwin, in the area just south of the eastern Banda Sea (Bjerkness, 1969). Primary productivity is tightly coupled to wind stress, which controls upwelling formation and intensity. Thus, reconstructing of paleo-PP would make it possible to estimate long term variations in the Australian and Indonesian winter monsoon system. The length of the dry season is also related to ENSO; during El Niño events, northern Australia experiences longer dry seasons (although more intense rain in the wet seasons than during normal years) (Taschetto et al., 2009).

\section{Material and methods}

\subsection{Recovery and age control of core MD98-2175}

Core MD98-2175 was retrieved by the RV Marion-Dufresne during the IMAGES IV cruise, in the eastern Banda Sea $\left(5^{\circ} 00^{\prime} 16 \mathrm{~S}-133^{\circ} 26^{\prime} 76 \mathrm{E}\right)$ at a water depth of $2382 \mathrm{~m}$, on a relatively flat plateau located on the north eastern slopes of the Kei Islands (Fig. 1). This plateau is separated by deep sea trenches from Irian Jaya to the north and the Arafura Shelf (and Aru Islands) to the east. The Kei Islands are relatively small, and do not possess large rivers. Thus, fluvial deposits and turbidites are limited in the core. The sediment consists of homogeneous fine olive grey clays rich in calcareous nannofossils.

The oxygen isotopic composition of the planktonic foraminifera Globigerinoides ruber was analysed at $10 \mathrm{~cm}$ intervals in the upper $20 \mathrm{~m}$ of the core and at $50 \mathrm{~cm}$ intervals between 20 and $31 \mathrm{~m}$. Nine ${ }^{14} \mathrm{C}$ dates were obtained on shallow dwelling planktonic foraminifera (G. ruber and a mix-

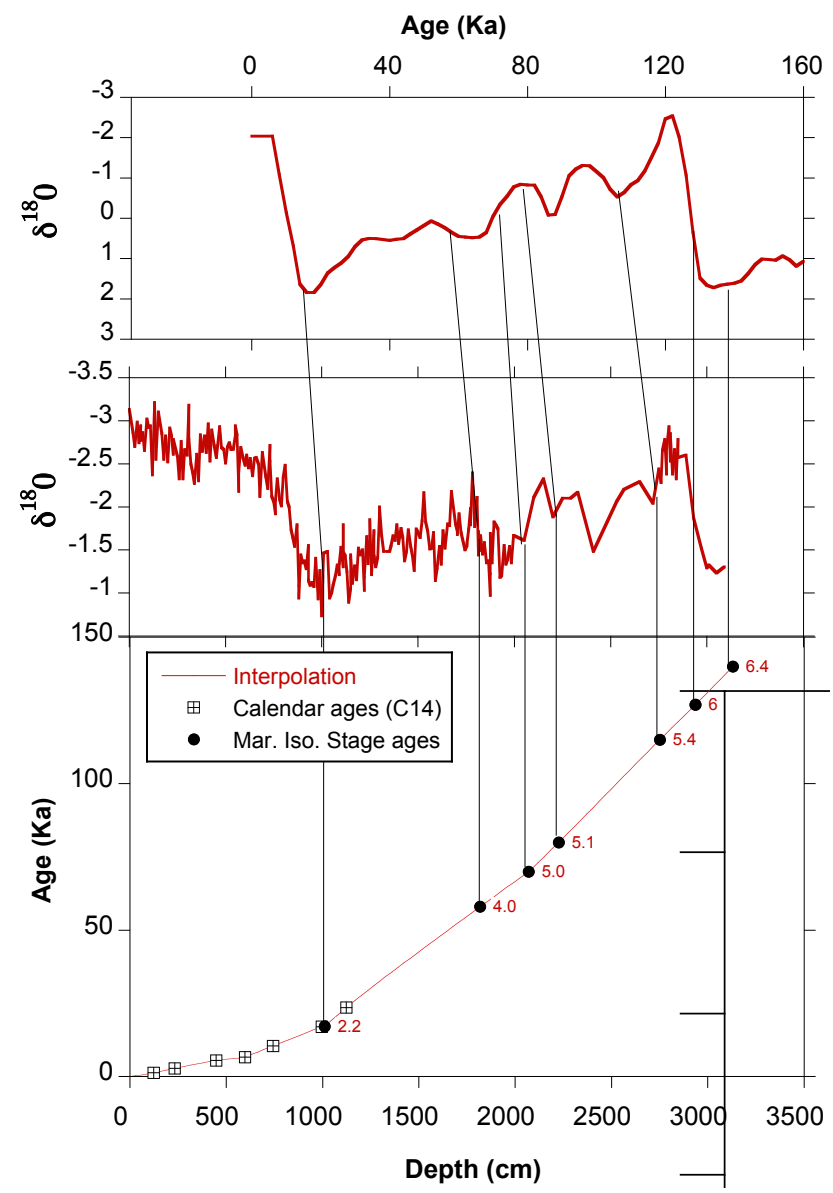

Fig. 3. (A) Tropical $\delta^{18} \mathrm{O}$ stack from Bassinot et al., 1994; (B) $\delta^{18} \mathrm{O}$ of $G$. ruber from MD98-2175 on a depth scale; (C) sedimentation rate curve for core MD98-2175. Open squares are calendar ages from ${ }^{14} \mathrm{C}$ measurements performed on $G$. ruber and filled circles mark of marine isotopic stages from $\delta^{18} \mathrm{O}$ of G. ruber. Vertical lines mark the $\delta^{18} \mathrm{O}$ tie-points used in this study.

ture of G. ruber andGlobigerinoides sacculifer in 2 cases). Calendar ages were obtained by converting the ${ }^{14} \mathrm{C}$ dates using IntCal09 (Reimer et al., 2009). We used a reservoir age of 515 years, which is an average of 6 reservoir ages from the northern Australian seas. For intervals that are beyond the limit for accurate ${ }^{14} \mathrm{C}$ dating, the depth-age conversion is based on the correlation of the planktonic $\delta^{18} \mathrm{O}$ record to the low-latitude oxygen isotope stack of Bassinot et al. (1994). Depth-to-age conversion was conducted through a linear interpolation between dated tie points (Fig. 3). Sedimentation rate is in the order of $47 \mathrm{~cm}$ per thousand years $\left(\mathrm{cm} . \mathrm{kyr}^{-1}\right)$ in the upper $10 \mathrm{~m}$ of the core and $17 \mathrm{~cm} \mathrm{kyr}^{-1}$ between 10 and $35 \mathrm{~m}$.

\subsection{Coccolith analysis}

Smear slides were prepared at a 5-cm interval in the upper $20 \mathrm{~m}$ of the core and at a $20-\mathrm{cm}$ interval for the remainder 
(20-31 m). The resulting temporal resolution is around 100 years in the upper $10 \mathrm{~m}$ of the series (interval $0-17 \mathrm{ka}$ ), in the order of 250 years between 10 and $20 \mathrm{~m}$ (interval 17-70 ka) and 1300 years below $20 \mathrm{~m}$ (interval $70-150 \mathrm{ka}$ ). A polarizing optical microscope (LEICA DMRBE) with a 50x oil immersion objective was used for automatic scanning of slides in cross-polarized light. Microscope stage motions and focus were computer-controlled. For each sample, forty fields of view were grabbed by a 2-megapixel Spot Insight (diagnostic instrument) camera. Each image (frame) captures $240 \times 180 \mu \mathrm{m}^{2}$ with a pixel area of $0.0225 \mu \mathrm{m}^{2}$. The amount of light going through the sample was precisely controlled. Coccoliths were automatically detected by SYRACO, a software program developed in C++ at CEREGE (Beaufort and Dollfus, 2004; Dollfus and Beaufort, 1999). By using an artificial neural network (ANN), SYRACO is adapted to pattern recognition. As described in Beaufort and Dollfus (2004), we used SYRACO in two steps. The first step makes it possible to extract all the coccolith species using a primary ANN. Then, in the second step, the software uses specific ANNs trained to recognize one species each and separate coccoliths from unwanted objects. During this second step, images of coccoliths are extracted and dumped into species-specific image files.

The relative abundance of Florisphaera profunda (\%Fp) was estimated as follows:

$\% \mathrm{Fp}=100 \times \mathrm{FP} /(\mathrm{FP}+\mathrm{SMP}+\mathrm{GEO})$

where FP, SMP and GEO are the number of $F$. profunda, small placoliths (essentially Emiliania huxleyi with some Gephyrocapsa ericsonii) and G. oceanica, respectively.

The reproducibility of the counts was tested on the top $8 \mathrm{~m}$ of the core. An investigation of coccolithophores was made using a former version of SYRACO, with a poorer-resolution camera (MICAM, $756 \times 582$ pixels). In this configuration, a pixel represents an area of $0.0256 \mu \mathrm{m}^{2}$. Two hundred images of $126 \times 97 \mu \mathrm{m}^{2}$ were grabbed. The ANN used with the MICAL camera was different from the one used with the diagnostic instrument camera because it was prepared with a different coccolith image collection. The offsetting of the microscope light was also different. The same set of slides was used, but it is almost certain that the areas scanned during the two scannings were different since only 40 (Diagnostic) or 200 (Micam) images, totaling an area of $4 \mathrm{~mm}^{2}$, were randomly grabbed on the entire area $\left(800 \mathrm{~mm}^{2}\right)$ of the slide. The data sets are, therefore, relatively independent. The average $95 \%$ confidence interval for the estimation of $\% \mathrm{Fp}$, which depends on the number of coccoliths counted per sample (Mosimann, 1965) corresponds to a reproducibility better than $\pm 5 \%$ in each of the two series. The average difference between the pair of results is less than 2\% (Fig. 4). One of us (LB) counted the first $>200$ coccoliths contained in 10 test samples with a standard polarising microscope. The estimated $\% \mathrm{Fp}$ from these counts are in perfect agree-

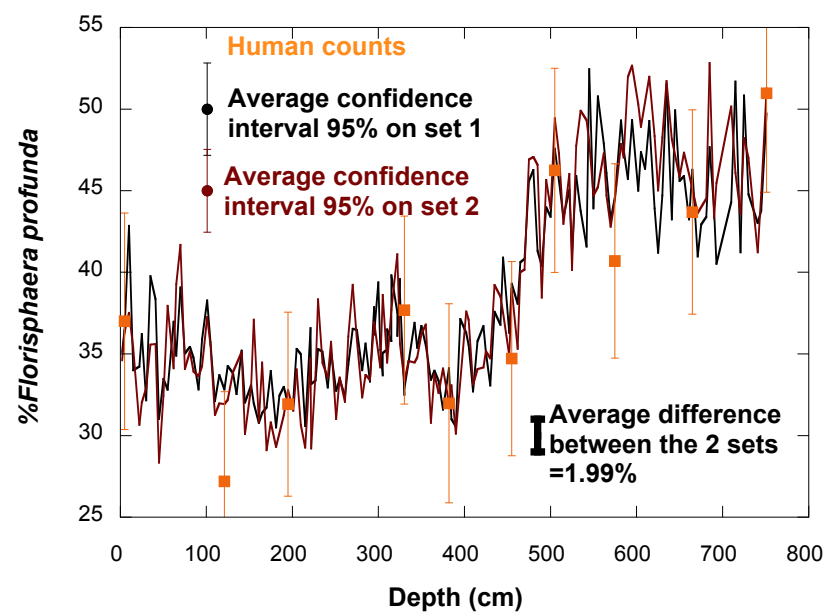

Fig. 4. Variations of the percentage of $F$. profunda obtained from the top $8 \mathrm{~m}$ of core MD98-2175 with two different cameras (red: MICAM, black: Diagnostic Inst.). Average confidence intervals and the average different between the two set of measurements are given. The orange dots, with their associated $95 \%$ confidence intervals, represent $\%$ Fp values resulting from a human count of coccoliths assemblages in 10 samples.

ment with the estimates obtained with the automated technic within a $95 \%$ confidence interval.

\subsection{Use of coccoliths as paleoproductivity indicators}

The coccolithophores are phytoplankton organisms that are widespread and abundant in the world's oceans. Because they are photosynthetic organisms, they must remain within the photic zone, and most species are found within the upper $80 \mathrm{~m}$ of the water column. This part of the photic zone is often depleted in nutrients and the productivity is highest just above the nutricline. When the ocean is strongly stratified and the nutricline is too deep in the photic zone, the primary production is low. A few species (e.g. Florisphaera profunda, Gladiolithus spp. and Algirosphaera spp.) are adapted to low light environments and are commonly found between 80 and $180 \mathrm{~m}$ (Okada and Honjo, 1973). The relative abundance of $F$. profunda (the most abundant of the three deep living taxa) may serve to monitor the depth of the nutricline (Molfino and McIntyre, 1990). A high relative abundance of $F$. profunda indicates a deep nutricline and low productivity in shallow waters (and the reverse). The $F$. profunda index (\%Fp) has been calibrated using data on the percentage of $F$. profunda (Fp) in a total of 400 counted coccoliths (total coccoliths $=$ TC) in 96 core top samples from a large variety of environments in the Indian Ocean (Beaufort et al., 1997). This index $(\% \mathrm{Fp}=100 \times \mathrm{Fp} / \mathrm{TC})$ was correlated to the estimated modern PP based on a compilation of 12-years of satellite observations with the Coastal Zone Colour Scanner (CZCS) (Antoine et al., 1995) to produce the simple transfer function: $\mathrm{PP}=617-(279 \log [\% \mathrm{Fp}+3])$ 
(Beaufort et al., 1997). The use of $F$. profunda as an indicator of PP is now commonly used by nannopaleontologists (e.g. Fernando et al., 2007; Incarbona et al., 2008; Liu et al., 2008; Lopez-Otalvaro et al., 2008). In core MD98-2175, the species belonging to the genera Gephyrocapsa, Emiliania and Florisphaera represent more than $90 \%$ of the coccolithophore assemblages. Thus, in core MD98-2175, the \%Fp is calculated only using these taxa, as is proposed elsewhere (Flores et al., 2000). In doing so, there are minor differences compared with the use of the entire assemblage.

\subsection{Analysis of pollen data}

Quantitative reconstructions of austral summer rainfall and the number of dry months were derived from pollen data from core MD98-2175 (Kershaw et al., 2006; Kershaw and van der Kaars, 2007) using a newly developed set of transfer functions for palynological data from Indonesian waters. The functions were developed by one of us (SvdK) in the course of on-going work on modern pollen distribution in this region. The modern pollen distribution dataset used covers the Indian Ocean adjacent to northwestern Australia and southern Indonesia and contains 113 core-top samples collected during Australian (van der Kaars and De Deckker, 2003), Indonesian-Dutch (van der Kaars, 2001), and FrenchIndonesian SHIVA (1991) and BARAT (1994) cruises as well as cores collected in the Timor Sea by the German research vessel Sonne during the SO185 cruise. This present work follows the development of transfer functions that can be used both with terrestrial and marine Australian palynological records (Cook and van der Kaars, 2006; van der Kaars et al., 2006). Both transfer functions are based on percentage values of 116 common (occurring more than twice) tree and herbaceous taxa to produce the proxy climatic series. Leaveone-out cross validation of the climatic estimates yielded an $r^{2}$ of 0.65 for summer rainfall and 0.80 for the number of dry months. The dry months are those that receive less than $70 \mathrm{~mm}$ of rain (or less than the monthly value of the local temperature (in ${ }^{\circ} \mathrm{C}$ ) multiplied by two). The pollen-based estimates were detrended by removing the first factor of a singular spectrum analysis (Vautard and Ghill, 1989) using the Analyseries software (Paillard et al., 1996). This detrending enabled extraction of the long term $\left(>1 / 80 \mathrm{kyr}^{-1}\right)$ variability leaving precessional type dynamics intact.

\section{Results}

\subsection{Representation of $\% \mathrm{~F}$. profunda}

The core contained a generally abundant nannofossil assemblage (typically 10 to 30 coccoliths per field of view). The relative abundance of $F$. profunda varied between 25 and 73 percent, which is large in comparison with the reproducibility (Fig. 4). This range corresponds to a large changes of reconstructed primary productivity (varying between 92 and $\left.214 \mathrm{gC} . \mathrm{m}^{-2 .} \mathrm{yr}^{-1}\right)$. Intervals of peak primary production are observed at 160, 135, 109, 87, 62, 43, 18 and $1 \mathrm{ka}$ (Fig. 5a). The average time interval between two adjacent productivity maxima is, therefore, $\sim 23 \mathrm{kyr}$, clearly showing the importance of precessional forcing in the production dynamics of this area. The high sampling resolution and the small standard deviations make it possible to clearly reconstruct the symmetrical shape of primary production fluctuations. For instance, between 23 and $11 \mathrm{ka}$, the series contains 71 points having an average of $170 \mathrm{gC} \mathrm{m}^{-2} \mathrm{yr}^{-1}$ (range $=150-203$ and standard deviation $=10$ ), well above the values found in the periods preceding and following.

The PP series has been resampled at a regular time interval of 1000 years. Time-series analysis (Blackman-Tukey and MTM), performed using the Analyseries software (Paillard et al., 1996), shows two main frequencies (Fig. 5e). The dominant frequency is at $23.3 \mathrm{kyr}^{-1}$, which corresponds to the main precession cycle $\left(23.3 \mathrm{ky}^{-1}\right)$. The second frequency corresponds to the obliquity cycle at $41.0 \mathrm{ky} r^{-1}$. Longerterm cycles, which could have been related to the global ice volume (i.e. $\sim 100 \mathrm{ky}^{-1}$ ) are absent from this time series. Cross correlation (Blackman-Tukey) between the precession (in its standard definition of Param. $\$=\mathrm{e} \cdot \sin (\varpi)$ where $\varpi$ is the vernal point) and \%FP indicates a phase of -0.91 radian, equivalent to a phase-lock with an equatorial daily insolation for August 15th at a period of $23.4 \mathrm{kyr}$. At this periodicity, the coherency between $\% \mathrm{Fp}$ and precession is 0.97 , which is above a confidence level of $99.99 \%$ (0.91) for a bandwidth of 0.02. Because the chronology is based in the older part of the record ( $>50-\mathrm{ka}$ ) on $\delta^{18} \mathrm{O}$ tuning, implying lower chronological precision, it is reinsuring that the phase of PP with precession appears to stay constant all along the record (e.g. Fig. 6b).

\subsection{Rainfall levels and length of dry season as indicated by pollen transfer functions}

In order to estimate past dynamics of the Australian monsoon, we concentrate on two palynological proxies: 1) the amount of summer rainfall as an index of the summer monsoon; and 2) the number of dry months, which should relate to the length of the winter monsoon . The long-term patterns are similar for the two proxies, with drier (wetter) summer conditions and longer (shorter) dry season during interglacials (glacials). The fact that a longer dry season corresponds to a wetter summer monsoon agrees with present inter-annual monsoon dynamics; El Niño years are characterized by a shorter and wetter summer monsoon season, and the dry season lasts longer (Moron et al., 2009, 2010; Taschetto et al., 2009). The long-term pattern follows the glacial/interglacial cycles with a $\sim 100 \mathrm{yr}$ periodicity (Fig. 5 c, g). Shorter-term variations of the summer rainfall show a complex signal with 24 and $44 \mathrm{kyr}$ periodicities that only show little significance (Fig. 5c, g). A 23-kyr cycle is not readily observed in the summer rainfall data but is clearly 


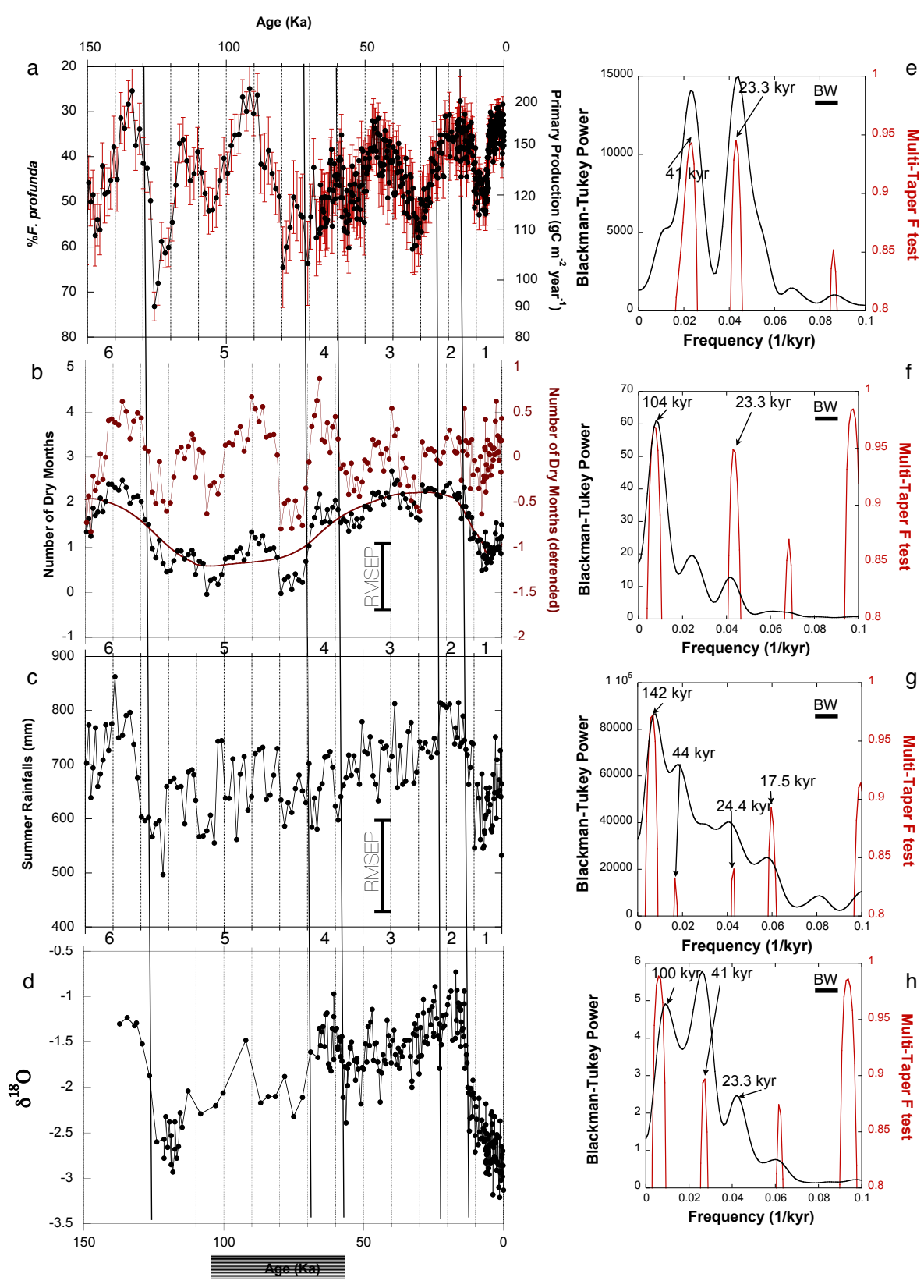

Fig. 5. MD98-2175 record (left column) and associated time series analysis (right column): (a) Percentage of $F$. profunda (left scale) (with its estimated primary production (right logarithmic scale) and its associated confidence interval (red error bars); (b) number of dry months estimated from palynology (black: raw data, smoothed line: first factor of a Singular Spectrum Analysis; red detrended data, vertical line is the Root Mean Square Error of Prediction (RMSEP =1.6)); (c) summer rainfall in mm, vertical line is the Root Mean Square Error of Prediction (RMSEP = 182); and (d) $\delta^{18} \mathrm{O}$ from G. ruber. (e-h) The time series analysis, Blackman-Tukey (black) and Multi-Taper Method (F test), are presented with indication of Band Width (BW and horizontal bars) and period of important peaks.

visible in the number of dry months, and corresponds to a significant peak in the spectral analysis results (Fig. 5f). Once the time-series is detrended to remove long-term variations, the precessional pattern is seen even more clearly in the number of dry months time series (Fig. 5b).

\subsection{Estimation of the length of the winter monsoon}

Figure 5 shows the striking correspondence between the detrended series representing the number of dry months and the primary productivity series. It is also possible to estimate the length of the upwelling season from the PP estimates knowing the seasonal and interannual variability from 
MODIS. As can be readily seen from Figure 2, the seasonality of the oceanic production in the Banda Sea is only based on two phases, one with a low monthly primary production (Pmin), and one with a high primary production (Pmax). Pmin is the base line of $0.2 \mathrm{mg}$ Chlorophyl $\mathrm{A} \mathrm{m}^{-3}$, which is equivalent here to $8 \mathrm{gC} \mathrm{m}^{-2}$ month $^{-1}$ (Antoine et al., 1997). Pmax depends on the yearly primary production (see Fig. 2) and here we have estimated the relationship between PP and $P \max$ as $[\mathrm{Pmax}=0.12+0.15 \cdot \mathrm{PP}]$ using the El Niño, La Niña and mean curves (Fig. 2). It is possible to calculate the upwelling season length (USL) as a function of PP, Pmin and Pmax using the equation [USL $=(\mathrm{PP}-(12 \cdot \mathrm{Pmin})) /(\mathrm{Pmax}-$ Pmin)]. Note that Pmax-Pmin aims to reproduce the increase of PP when the winter monsoon is longer and more intense. With this model (equation) the length of the upwelling season and its intensity both contribute to the yearly primary production, and are converted into "upwelling season duration" (Fig. 6b). The anomalies (from record average) displayed in the length of the upwelling (derived from coccolithophores data) and dry seasons (estimated from palynological data) are in relatively good agreement (Fig. 6c). The amplitude of the precession signal is, however, often larger for the upwelling length anomalies than for the dry season length anomalies. This may be due to the fact that the upwelling season is longer ( 3 to 4 months) than the dry season (1-2 months). The two series were re-sampled at a resolution of 1000 years between 1 and $150 \mathrm{ka}$ and then averaged. The resulting pattern is very similar to that in the Niño3 model of past ENSO variability proposed by Clement et al. (1999) (Fig. 6b). The correlation between this model and the average length of the winter monsoon season is $r=0.7$.

\section{Discussion}

\subsection{Development of ENSO-like conditions}

As seen above, reconstructions made using combined pollen and coccolith series from core MD98-2175 show that, in response to precessional forcing, the duration of the Australian winter monsoon has varied from -0.6 to +0.3 months. The significant correlations between the ENSO Niño3 model and the multiproxy estimate for the length of the winter monsoon, and equivalent fit in the modern climates (QuikSCAT and MODIS satellite data compared to Niño3) strongly support an interpretation that past ENSO dynamics form the basis of observed changes in the paleo-data from core MD982175. There is, however, a difficulty with such an interpretation. Using the Zebiak-Cane model (Zebiak and Cane, 1987), Clement et al. (1999) estimated that there would be at most (least) $\sim 180(\sim 20)$ warm events (El Niño) and $\sim 150(\sim 50)$ cold events (La Niña) per 500 years and that the amplitude in temperature of those events would not change dramatically $(25 \%)$. This corresponds, using the estimated PP from satellite data (with 205,141 and $175 \mathrm{gC} \mathrm{m}^{-2}$ year $^{-1}$ for $\mathrm{El}$

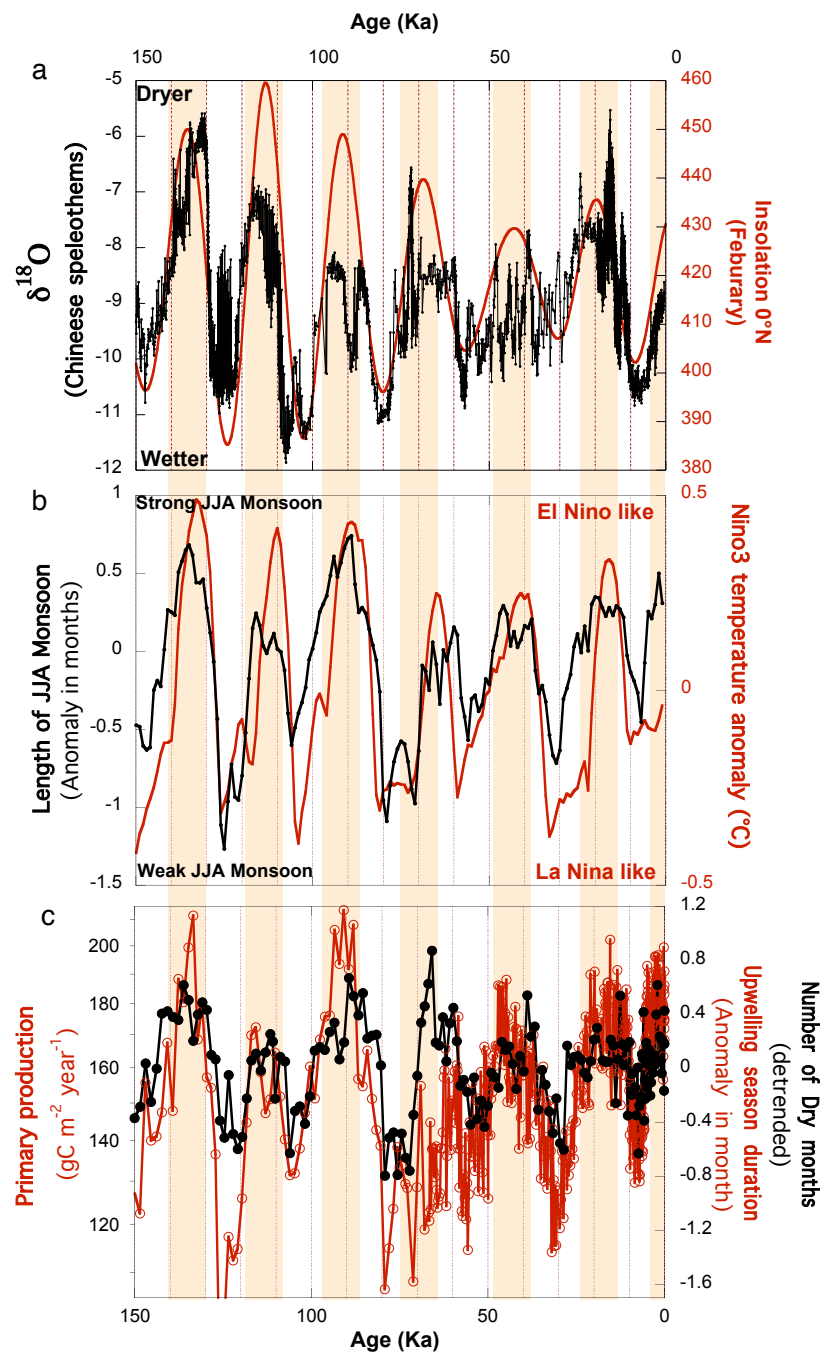

Fig. 6. Comparison of Australia Winter monsoon dynamics with ENSO modeling, and speleothem data from China. (a) $\delta^{18} \mathrm{O}$ record from Chinese Speleothems (Hulu, and Sanbao) from Wang et al. (2008) in black, Insolation at the Equator in August 15th (red); (b) Anomaly of the length of the Australian Winter Monsoon in month reconstructed from coccolith and pollen data (black); Niño3 temperature anomalies estimated with the Zebiak and Cane model (Clement et al., 1998); c) Primary Production and its estimated upwelling season anomaly in months in red and number of dry months (palynology). Note that the two curves have the same scale in month on the right axis, and that the color of labels to the right refer to the color of the curves.

Niño, La Niña and normal years) to a range of PP of 166 to $183 \mathrm{gC} \mathrm{m}^{-2}$ year $^{-1}$. Those changes would not be sufficient to explain the large variations in the length and intensity of the winter monsoon exhibited by the pollen and coccolith data from the Banda Sea core and in its PP record which ranges from 90 to $213 \mathrm{gC} \mathrm{m}^{-2}$ year $^{-1}$. It should be noted that, in other simulations of the same model, if the number of warm events is further diminished in the early Holocene, 
the number of cold events is also diminished (Clement et al., 2000). In contrast, our data point to regular (every $23 \mathrm{kyr}$ ) more extreme shifts in ENSO with an amplitude similar to inter-annual climate variations observed since 1997. The ENSO system would be locked in a constant El Niño phase or in a constant La Niña phase, which is not physically possible. Some studies have indicated important weakening of El Niño in the middle/early Holocene (Rein et al., 2005; Moy et al., 2002; Rodbell et al., 1999) which agree well with our dataset, however, other studies have shown that ENSO cycles have been constantly present during the last 35 or $135 \mathrm{kyr}$ (Grelaud et al., 2009; Tudhope et al., 2001, respectively). Both palaeo datasets and model results do not support a complete disappearance of El Niño in favor of La Niña over a long period of time. The atmospheric and oceanographic conditions that prevail during the two current opposite phases of ENSO may have been the mean states of low latitude climate during long periods of time and can be described instead as "ENSO-like".

\subsection{The monsoon in China and movement of the ITCZ}

The speleothems from Hulu, Sanbao and Dongge caves, all located between 108 and $111^{\circ} \mathrm{E}$ and 25 and $32^{\circ} \mathrm{N}$ provide a very detailed record of the intensity of the summer monsoon in China from oxygen isotope measurements (Wang and Ding, 2008). As the Australian-Indonesian (austral) winter monsoon occurs at the same time as the (boreal) summer Asian monsoon, it is informative to compare the variability recorded in the MD98-2175 records with that of the Chinese speleothems. The composite Chinese speleothem $\delta^{18} \mathrm{O}$ record is dominated by precessional forcing and is in phase with the local mid-winter insolation (Wang and Ding, 2008). The same phase is found in the Banda Sea record. The phasing between the two records is stable during the last 150-kyr and therefore independent on the methodology used to built the chronology of the Banda Sea core $\left({ }^{14} \mathrm{C}\right.$ or $\left.\delta^{18} \mathrm{O}\right)$ (Fig. 6a, b and Fig. 7). The close resemblance between the two datasets appears clearly in Fig. 6a, b. This similarity suggests that the two monsoon systems are related, or at least are controlled by the same forcing mechanism. It is surprising that drier Chinese summer monsoon periods occurred at times of more intense winds in the Banda Sea and longer dry seasons.

Employing a simplistic model, it might be expected that the more intense Austral winter monsoon winds might have picked up a lot of water vapor from the ocean during their journey over Indonesia and South China Sea (and the Pacific) and delivered it into mainland Asia. Alternatively, the ITCZ might have migrated to a far northerly position during JJA causing a strong Asian monsoon, which would have corresponded to drier winter Australian monsoon conditions. However, these scenarios seem unlikely because the amount of rain received in China during the summer monsoon is not directly related to ENSO dynamics (e.g. Ropelewski and

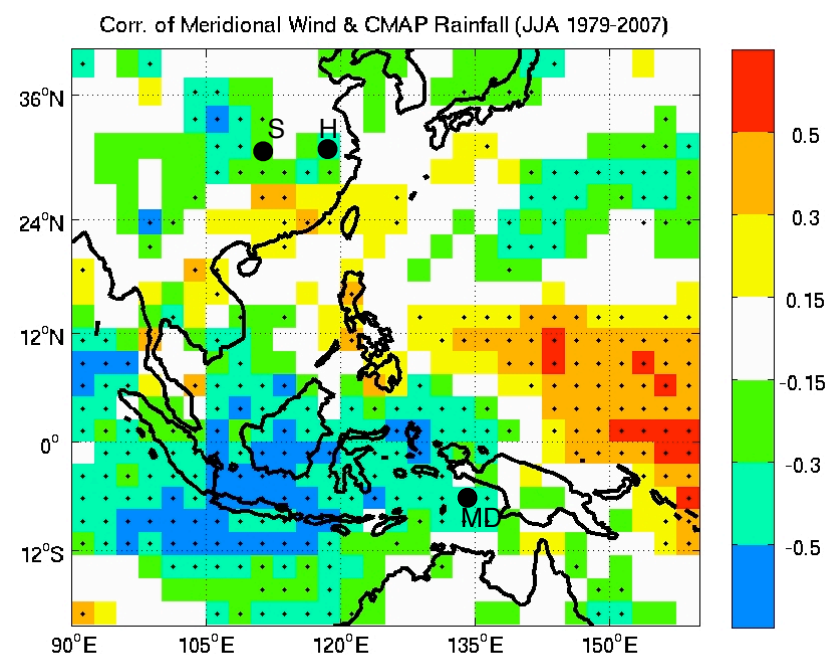

Fig. 7. Correlation between June, July and August (JJA) meridional winds $\left(124^{\circ}-132^{\circ} \mathrm{E}, 8^{\circ} \mathrm{S}\right.$ and Equator) and JJA rainfall in two datasets $(\mathrm{CMAP}=$ satellites + rain-gauges from 1979 to 2007). Despite the noise, different patterns are consistent to each other with weak (but significant) negative correlations over China (less rainfall when southerly winds increase). The dots indicate $90 \%$ significance level. Correlation between the rain and the meridional component of the wind $\left(124^{\circ}-132^{\circ} \mathrm{E}, 8^{\circ} \mathrm{S}\right.$ and Equator) from 1979 and 2007. Position of the Hulu $(\mathrm{H})$ and Sanbao $(\mathrm{S})$ speleothem records and of MD98-2175 (MD) are also given in the map.

Halpert, 1987) or is related in a very complex way (Lau and Weng, 2001). We compared the recent relationship between the JJA meridian component of the wind in the western Banda Sea $\left(\left(124^{\circ}-132^{\circ} \mathrm{E}, 8^{\circ} \mathrm{S}\right.\right.$ and Equator) with the rain anomaly in JJA for the period from 1979 to 2007 (Fig. 7). A drier area appears across the Australian-Indonesian region near the origin of the acceleration of the southerly winds; and wet anomalies appear above the Indo-Pacific warm pool (IPWP) probably due to the strengthened low-level convergence there. When the ITCZ is reinforced over the IPWP during the boreal summer, the rainfall tends to be anomalously low across most of mainland China. The patterns seen in present climates and the paleo-data each point toward a drier East Asian summer monsoon in China at times of stronger winter monsoon winds in the Banda Sea. Simple explanations based on spatially-homogeneous forcing linked to ENSO or ITCZ migration are therefore not necessarily valid here. We suggest that the observed evolution of the strength of the Australian and East Asian JJA monsoons depends on the evolution of the ocean/land thermal gradients related to the seasonal hemisphere path of insolation forced by precession. It could also be noted that the performance of current AGCM forced by prescribed SST to simulate interannual rainfall anomalies of boreal summer monsoon across China is rather poor (i.e. Li et al., 2010). This is associated with the fact that large-scale migrations of the ITCZ do 
probably not have a major role in driving interannual rainfall anomaly across China.

Simulations with the IPSL CM4 ocean-atmosphere coupled model on several orbital configurations show the influence of precession on monsoon and tropical climate (Braconnot et al., 2008). Our results show a very similar pattern. In those simulations, precession appears to largely control the response of the monsoon and induces large changes in the seasonal evolution of the Equatorial Pacific; each contributing to a large redistribution of energy. This feature is consistent with other simulations such as those made by Zheng et al., 2008, Cane et al., 2006, Clement et al., 1999, 2000.

\subsection{Relationship between the Australian summer monsoon and other monsoon systems in the Holocene}

The strong imprint of precession observed in the Banda Sea is a common feature of tropical climates (e.g. Pokras and Mix, 1987; Molfino and McIntyre, 1990; Beaufort et al., 1997; Schneider et al., 1997; Villanueva et al., 1998; Reichart et al., 1998). All of these have the same phase (beginning of August or February depending on the sign of the climate phenomenon), which is also observed in the Chinese speleothems and our Banda Sea records. Ruddiman (2006) proposed that the monsoon is in phase with summer insolation as models predict (e.g. Kutzbach, 1981). However, other monsoon records for which precession is not the dominant spectral feature, have a different phase in the precession band (often May or November) (Clemens and Prell, 2003; Clemens et al., 1991; Ziegler et al., 2010a). Because most of these latter records come from the Arabian Sea where the summer monsoon is well expressed, this late phase is usually accepted as the "monsoon phase", and the records that display an early phase are considered as independent tropical climatic phenomena. Our findings, that all these records are responding to the same phenomenon, thereby explaining their synchronicity, are in agreement with Ruddiman, 2006; Reichart et al., 1998; Ziegler et al. 2010b; Braconnot et al., 2008; Wang et al., 2005, 2008; Zheng et al., 2008. It seems, therefore, that the "Global Monsoon" concept, which has been discussed for modern climates (Wang and Ding, 2008; Trenberth et al., 2000) is also valid for the paleo-variability of the tropical climates. Of course, the relevance of the Global Monsoon concept should be adapted to the type of paleoclimate records considered (rainfall reconstructions across continents should be, for example, far noisier than wind reconstructions across oceanic domains); we simply stress here the synchronism between different regional monsoon systems. Because of the dominance of the precessional signal over obliquity and eccentricity (which are seen more in high latitude climates and are more representative of ice volume), variations in the past global monsoon system may have been relatively independent of ice volume variations. This is demonstrated by examining how the several sub-monsoon

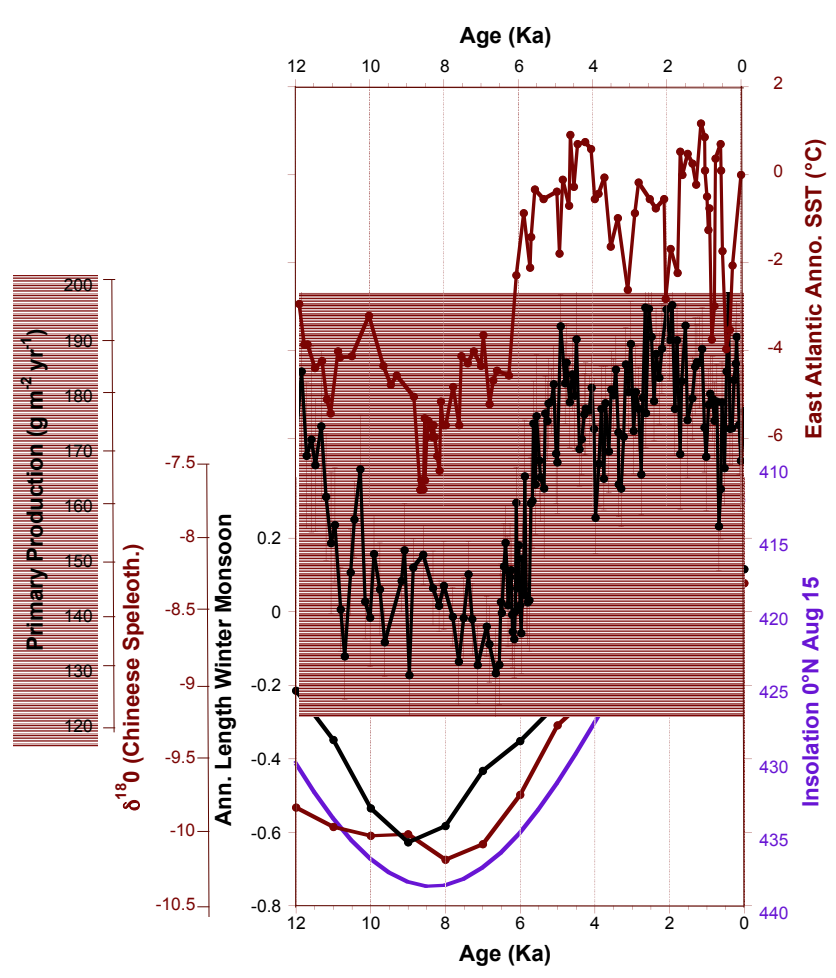

Fig. 8. Dynamics of the monsoons in the Holocene: from top to base: Sea surface temperature anomaly $\left({ }^{\circ} \mathrm{C}\right)$ in the eastern Atlantic ocean (deMenocal et al., 2000) in red, MD98-2175 record of primary production in black; insolation at the Equator in August (purple); Precession cycle stack of speleothem data from China (red) and anomaly in the length of the winter monsoon in months (black) (the two records were resample at 1000 year intervals, cut into seven segments covering each a precession cycle (starting at $0,21,46,71$ 94116 and $137 \mathrm{ka}$ ). The age at the beginning of each segment was subtracted to the entire time column so each segment starts at zero BP). finally the seven segments were stacked together by computing their average at any given time).

systems evolved during the Holocene when there were relatively small variations in ice-volume (Fig. 8). In the Banda Sea, the MD98-2175 record shows a strong shift in monsoon activity at about 6000 years. This shift is synchronous with an increase in aridity seen in the Sahel and Sahara in the mid Holocene in palaeo-records of the African monsoon from the western Atlantic Ocean (deMenocal et al., 2000). This mid Holocene change in the North African monsoon regime has been described in many studies (Servant and Servant-Vildary, 1980; Gasse and Van campo, 1994; Petit-Maire et al., 1997; Kropelin et al., 2008) and extends also to East Africa (see references in Gasse, 2000; Vincens et al., 2005). Mid-Holocene monsoon changes are also observed in the Arabian Sea area (Fleitmann et al., 2003; Fleitmann et al., 2007), the Tibetan Plateau (Gasse et al., 1991), and in Eastern Asia (Wang et al., 2008). Changes in ENSO dynamics are observed synchronously (Moy et al., 2002; Rein et al., 2005; Rodbell et al., 1999; Haug et al., 2001; Grelaud et al., 2009; Conroy et 
al., 2008). In the Holocene, the monsoon follows the same phase in the precession band as in the seven previous precession cycles (Fig. 8). Therefore, as suggested quite some time ago by Kutzbach (1981), it appears that changes in lowlatitude summer insolation drive the dynamics of the monsoon, with a very short time lag. The Holocene data indicate that, because of the early response of the tropics to insolation forcing and the relatively delayed response of ice volume, changes in records from the tropical climates often precede global changes in $\delta^{18} \mathrm{O}$ records (Beaufort et al., 1997; Beaufort et al., 2001). This is also visible at the end of the penultimate interglacial in our records (Fig. 6c), where changes in pollen and coccolith data precede the changes of $\delta^{18} \mathrm{O}$ occurring at the beginning of Marine Isotopic Stage 5.4 (5d) by about 5000 years. It is therefore not possible to attribute large scale changes in tropical hydrological systems observed at precession time scales to the global variability of ice volume. Conversely, our data suggest that at the time when the Earth enters an ice-age, the tropics will have already held their present precession climate configuration for some few thousand years.

\section{Conclusions}

The dynamics of the Australian winter monsoon have been reconstructed using two different types of proxies in the Eastern Banda Sea. Primary production, the length of the winter monsoon, and the amount of rainfall during the summer were estimated for the last 150,000 years. The summer monsoon rainfall follows the glacial-interglacial dynamics, whereas the winter monsoon proxies (primary production and length of the dry season) are strongly influenced by precessional cycles. The austral winter monsoon dynamics are in phase with low latitude insolation in August. A synchrony with other regional monsoon systems and ENSO is found at precession time scales, pointing to common climatic forcing of the different regional systems. These latest observed changes in winter monsoonal variability in the low latitudes, already established for a few thousand years, form a pattern similar to that seen at the onset of the glaciations during MIS5, and indicate that tropical climates precede glaciations by a few thousand years.

Acknowledgements. We thank Noëlle Buchet for her technical assistance. Funds for this study were provided by the French Agence Nationale de la Recherche (ANR) program award number ANR-05 PICC, and from the European Community's Seventh Framework Program under grant ENV.2009.1.1.1.1 "Past4Future". The radiocarbon dating was supported by the Australian Institute of Nuclear Science and Engineering (AINSE) grant 06/183 to SvdK and LB. SvdK gratefully acknowledges the support of a Logan Research Fellowship from Monash University, and funding from The Australian Research Council (ARC). We thank Ellyn Cook for revision of the text and acknowledge the thoughtful comments made by Martin Ziegler and an anonymous reviewer which, all, greatly improved the manuscript.
Edited by: T. Kiefer

\section{References}

Antoine, D., André, J.-M., and Morel, A.: Oceanic primary production 2. Estimation at global scale from satellite (coastal zone color scanner) chlorophyll, Global Biogeochem. Cy., 10, 57-69, 1995.

Bassinot, F. C., Labeyrie, L. D., Vincent, E., Quidelleur, X., Shackleton, N. J., and Lancelot, Y.: The astronomical theory of climate and the age of the brunhes-matuyama magnetic reversal, Earth Planet. Sci. Lett., 126, 91-108, 1994.

Beaufort, L., Lancelot, Y., Camberlin, P., Cayre, O., Vincent, E., Bassinot, F., and Labeyrie, L.: Insolation cycles as a major control of the Equatorial Indian Ocean primary production, Science, 278, 1451-1454, 1997.

Beaufort, L., de Garidel Thoron , T., Mix, A. C., and Pisias, N. G.: Enso-like forcing on oceanic primary production during the late Pleistocene, Science, 293, 2440-2444, 2001.

Beaufort, L. and Dollfus, D.: Automatic recognition of coccolith by dynamical neural network, Mar. Micropaleont., 51/1-2, 5773, 2004.

Bjerkness, J.: Atmospheric teleconnections from the Equatorial Pacific, Mon. Weath. R., 97, 163-172, 1969.

Braconnot, P., Marzin, C., Gregoire, L., Mosquet, E., and Marti, O.: Monsoon response to changes in earth's orbital parameters: Comparisons between simulations of the Eemian and of the Holocene, Clim. Past., 4, 281-294, 2008.

Cane, M. A., Braconnot, P., Clement, A., Gildor, H., Joussaume, S., Kageyama, M., Khodri, M., Paillard, D., Tett, S., and Zorita, E.: Progress in paleoclimate modeling, J. Climate, 19, 5031-5057, 2006.

Clemens, S., Prell, W. L., Murray, D., Shimmield, G., and Weedon, G.: Forcing mechanisms of the Indian Ocean monsoon, Nature, 353, 720-725, 1991.

Clemens, S. C. and Prell, W. L.: A 350,000 year summer-monsoon multi-proxy stack from the Owen Ridge, Northern Arabian Sea, Mar. Geol., 201, 35-51, doi:10.1016/s0025-3227(03)00207-x, 2003.

Clement, A. C., Seager, R., and Cane, M. A.: Orbital controls on the El Niño/Southern Osciallation and the tropical climate, Paleoceanogr., 14, 441-456, 1999.

Clement, A. C., Seager, R., and Cane, M. A.: Suppression of El Niño during the mid-Holocene by changes in the Earth's orbit, Paleoceanography, 15, 731-737, 2000.

Conroy, J. L., Overpeck, J. T., Cole, J. E., Shanahan, T. M., and Steinitz-Kannan, M.: Holocene changes in Eastern Tropical Pacific climate inferred from a Galapagos lake sediment record, Quaternary Science Reviews, 27, 1166-1180, doi:10.1016/j.quascirev.2008.02.015, 2008.

Cook, E. J. and van der Kaars, S.: Development and testing of transfer functions for generating quantitative climatic estimates from Australian pollen data, J. Quat. Sci., 21, 723-733, 2008.

deMenocal, P., Ortiz, J., Guilderson, T., and Sarnthein, M.: Coherent high- and low-latitude climate variability during the Holocene warm period, Science, 288, 2198-2202, 2000.

Dollfus, D. and Beaufort, L.: Fat neural network for recognition of position-normalised objects, Neural Networks, 12, 553-560, 1999. 
Fernando, A. G. S., Peleo-Alampay, A. M., and Wiesner, M. G.: Calcareous nannofossils in surface sediments of the eastern and western south China Sea, Marine Micropaleontol., 66, 1-26, doi:10.1016/j.marmicro.2007.07.003, 2007.

Fleitmann, D., Burns, S. J., Mudelsee, M., Neff, U., Kramers, J., Mangini, A., and Matter, A.: Holocene forcing of the Indian monsoon recorded in a stalagmite from southern Oman, Science, 300, 1737-1739, 2003.

Fleitmann, D., Burns, S. J., Mangini, A., Mudelsee, M., Kramers, J., Villa, I., Neff, U., Al-Subbary, A. A., Buettner, A., Hippler, D., and Matter, A.: Holocene itcz and indian monsoon dynamics recorded in stalagmites from Oman and Yemen (Socotra), Quat. Sci. Rev., 26, 170-188, doi:10.1016/j.quascirev.2006.04.012, 2007.

Flores, J. A., Barcena, M. A., and Sierro, F. J.: Ocean-surface and wind dynamics in the Atlantic Ocean off Northwest Africa during the last 140000 years, Paleogeogr. Paleoclimatol. Paleoecol., 161, 459-478, 2000.

Gasse, F., Arnold, M., Fontes, J. C., Fort, M., Gilbert, E., Huc, A., Bingyan, L., Yuanfang, L., Qing, L., Melieres, F., Van Campo, E., Fubao, W., and Qingsong, Z.: A 13,000-year climate record from Western Tibet, Nature, 353, 742-745, 1991.

Gasse, F. and Van campo, E.: Abrupt post-glacial climate events in West Asia and North Africa monsoon domains, Earth and Planetary Science Letters, 126, 435-456, 1994.

Gasse, F.: Hydrological changes in the African tropics since the last glacial maximum, Quaternary Science Reviews, 189-211, 2000.

Grelaud, M., Beaufort, L., Cuven, S., and Buchet, N.: Glacial to interglacial primary production and El Niño-southern oscillation dynamics inferred from coccolithophores of the Santa Barbara basin, Paleoceanography, 24, 1201-1215, PA1203, doi:10.1029/2007PA001578, 2009.

Haug, G. H., Hughen, K. A., Sigman, D. M., Peterson, L. C., and Röhl, U.: Southward migration of the intertropical convergence zone through the Holocene, Science, 293, 1304-1308, 2001.

Incarbona, A., Di Stefano, E., Patti, B., Pelosi, N., Bonomo, S., Mazzola, S., Sprovieri, R., Tranchida, G., Zgozi, S., and Bonanno, A.: Holocene millennial-scale productivity variations in the Sicily channel (mediterranean sea), Paleoceanography, 23, doi:10.1029/2007pa001581, PA3204, 2008.

Kershaw, A. P.: A long continuous pollen sequence from NorthEastern Australia, Nature, 251, 222-223, 1974.

Kershaw, A. P., Bretherton, S. C., and van der Kaars, S.: A complete pollen record of the last $230 \mathrm{ka}$ from Lynch's crater, NorthEastem australia, Paleogeogr. Paleoclimatol. Paleoecol., 251, 23-45, doi:10.1016/j.palaeo.2007.02.015, 2007.

Kershaw, P. and van der Kaars, S.: Late Pleistocene pollen records of Australasia, in: Encyclopedia of Quaternary Science, edited by: Elias, S. A., Elsevier, 2613-2623, 2007.

Kershaw, P., van der Kaars, S., Moss, P., Opdyke, B., Guichard, F., Rule, S. and Turney, C.: Environmental change and the arrival of people in the Australian region, Before Farming, (online version) 2006/1 article 2, 2006.

Kropelin, S., Verschuren, D., Lezine, A. M., Eggermont, H., Cocquyt, C., Francus, P., Cazet, J. P., Fagot, M., Rumes, B., Russell, J. M., Darius, F., Conley, D. J., Schuster, M., von Suchodoletz, H., and Engstrom, D. R.: Climate-driven ecosystem succession in the Sahara: The past 6000 years, Science, 320, 765-768, doi:10.1126/science.1154913, 2008.
Kutzbach, J. E.: Monsoon climate of the early holocene: Climate experiment with the Earth's orbital parameters for 9000 years ago, Science, 214, 59-61, 1981.

Lau, K. M. and Weng, H. Y.: Coherent modes of global sst and summer rainfall over china: An assessment of the regional impacts of the 1997-98 El Niño, J. Climate, 14, 1294-1308, 2001.

Li, H., Dai, A., Zhou, T., Lu, J.: Reponses of East Asian summer monsoon to historical SST and atmospheric forcing during 19502000. Climate Dynamics, 34, 501-514, 2010.

Liu, C. L., Wang, P. X., Tian, J., and Cheng, X. R.: Coccolith evidence for Quaternary nutricline variations in the southern South China Sea, Marine Micropaleontol., 69, 42-51, doi:10.1016/j.marmicro.2007.11.008, 2008.

Lopez-Otalvaro, G. E., Flores, J. A., Sierro, F. J., and Cacho, I.: Variations in coccolithophorid production in the Eastern Equatorial Pacific at odp site 1240 over the last seven glacial-interglacial cycles, Marine Micropaleontol., 69, 52-69, doi:10.1016/j.marmicro.2007.11.009, 2008.

Molfino, B. and McIntyre, A.: Precessional forcing of the nutricline dynamics in the Equatorial Atlantic, Science, 249, 766769, 1990.

Moore, T. S., Marra, J., and Alkatiri, A.: Response of the Banda Sea to the southeast monsoon, Mar. Ecol. Prog. Ser., 261, 41-49, 2003.

Moron, V., Robertson, A. W., and Boer R.: Spatial coherence and seasonal predictability of monsoon onset across Indonesia, J. Climate, 22, 840-850, 2009.

Moron, V., Robertson, A. W., and Qian, J. H.: Local versus regional-scale characteristics of monsoon onset and post-onset rainfall over Indonesia. Clim. Dynam. 34, 281-299, 2010.

Mosimann, J. E.: Statistical methods for the pollen analyst: Multinomial and negative multinomial techniques, in: Handbook of paleontological techniques, edited by: Kummel, B. and Raup, D., Freeman, W. H., San Francisco, USA, 636-673, 1965.

Moss, P. T. and Kershaw, A. P.: The last glacial cycle from the humid tropics of Northeastern Australia: Comparison of a terrestrial and a marine record, Palaeogeogr. Palaeoclimatol. Palaeoecol., 155, 155-176, 2000.

Moy, C. M., Seltzer, G. O., Rodbell, D. T., and Anderson, D. M.: Variability of El Niño/Southern Oscillation activity at millennial timescales during the Holocene epoch, Nature, 420, 162-165, 2002.

Okada, H. and Honjo, S.: The distribution of oceanic coccolithophorids in the pacific, Deep Sea Res., 20, 355-374, 1973.

Paillard, D., Labeyrie, L., and Yiou, P.: Macintosh program performs time-series analysis, Eos Trans. AGU, 77, p. 379, 1996.

Petit-Maire, N., Beaufort, L., and Page, N.: Holocene climate change and man in the present day Sahara desert, in: Third millenium bc climate change and old world collapse, edited by: Nüzhet Dalfes, H., Kukla, G., and Weiss, H., Springer-Verlag, Berlin-Heidelberg, Germany, 297-308, 1997.

Philander, S. G. H.: El Niño Southern Oscillation phenomena, Nature, 302, 295-301, 1983.

Pokras, E. M. and Mix, A.: Earth's precession cycle and Quaternary climatic change in Tropical Africa, Nature, 326, 486-487, 1987.

Reichart, G. J., Lourens, L. J., and Zachariasse, W. J.: Temporal variability in the Northern Arabian Sea oxygen minimum zone (omz) during the last 225,000 years, Paleoceanogr., 13, 607-621, 1998. 
Reimer, P., Baillie, M., Bard , E., Bayliss, A., Beck, J., Blackwell, P., Bronk Ramsey, C., Buck, C., Burr, G., Edwards, R., Friedrich, M., Grootes, P., Guilderson, T., Hajdas, I., Heaton, T., Hogg, A., Hughen, K., Kaiser, K., Kromer, B., McCormac, F., Manning, S., Reimer, R., Richards, D., Southon, J., Talamo, S., Turney, C., van der Plicht, J., and Weyhenmeyer, C.: Intcal09 and marine09 radiocarbon age calibration curves, $0-50,000$ years cal bp, Radiocarbon, 51, 1111-1150, 2009.

Rein, B., Luckge, A., Reinhardt, L., Sirocko, F., Wolf, A., and Dullo, W. C.: El Niño variability off Peru during the last 20,000 years, Paleoceanography, 20, 18, Pa4003, doi:10.1029/2004pa001099, 2005.

Rodbell, D. T., Seltzer, G. O., Anderson, D. M., Abbott, M. B., Enfield, D. B., and Newman, J. H.: An similar to 15,000-year record of El Niño-driven alluviation in Southwestern Ecuador, Science, 283, 516-520, 1999.

Ropelewski, C. F. and Halpert, M. S.: Global and regional scale precipitation patterns associated with the El-Niño Southern Oscillation, Mon. Weather Rev., 115, 1606-1626, 1987.

Ruddiman, W. F.: What is the timing of orbital-scale monsoon changes?, Quaternary Science Reviews, 25, 657-658, doi:10.1016/j.quascirev.2006.02.004, 2006.

Schneider, R. R., Price, B., Müller, P. J., Kroon, D., and Alexander, I.: Monsoon related variations in Zaïre (Congo) sediment load and influence of fluvial silicate supply on marine productvity in the east equatorial Atlantic during the last 200,000 years, Paleoceanogr., 12, 463-481, 1997.

Servant, M. and Servant-Vildary, S.: L'environement quaternaire du bassin du tchad, in: The Sahara and the Nile - Quarternary environments and prehistoric occupation in Northern Africa, edited by: Williams, M. A. J., and Faure, H., A. A. Balkema, Rotterdam, The Netherlands, 133-162, 1980.

Taschetto, A. S., Ummenhofer, C. C., Sen Gupta, A., and England, M. H.: Effect of anomalous warming in the central Pacific on the Australian monsoon, Geophys. Res. Lett., 36, 5, L12704, doi:10.1029/2009g1038416, 2009.

Trenberth, K. E., Stepaniak, D. P., and Caron, J. M.: The global monsoon as seen through the divergent atmospheric circulation, J. Climate, 13, 3969-3993, 2000.

Tudhope, A. W., Chilcott, C. P., McCulloch, M. T., Cook, E. R., Chapell, J., Ellam, R. M., Lea, D. W., Lough, J. M., and Shimmield, G. B.: Variability in the El Niño-Southern Oscillation through a glacial-interglacial cycle, Science, 291, 1511-1517, 2001

van der Kaars, S.: Pollen distribution in marine sediments from the south-eastern Indonesian waters, Palaeogeogr. Palaeoclimatol. Palaeoecol., 171, 341-361, 2001.

van der Kaars, S. and Dam, M. A. C.: A 135,000-year record of vegetational and climatic change from the Bandung area, WestJava, Indonesia, Palaeogeogr. Palaeoclimatol. Palaeoecol., 117, 55-72, 1995. van der Kaars, S., De Deckker, P., and Gingele, F.: A 100,000-year record of annual and seasonal rainfall and temperature for northwestern Australia based on a pollen record obtained offshore, J. Quat. Sci., 21, 879-889, 2006.

van der Kaars, S. and De Deckker, P.: Pollen distribution in marine surface sediments offshore Western Australia, Rev. Palaeobot. Palynol., 124, 113-129, 2003.

Vautard, R. and Ghill, M.: Singular spectrum analysis in nonlinear dynamics, with applications to paleoclimatic time series, Physica, 35(3), 395-424, 1989.

Villanueva, J., Grimalt, J. O., Labeyrie, L. D., Cortijo, E., Vidal, L., and Turon, J.-L.: Precessional forcing of productivity in the North Atlantic Ocean, Paleoceanography, 13, 561-571, 1998.

Vincens, A., Buchet, G., Williamson, D., and Taieb, M.: A 23,000 yr pollen record from lake rukwa (8 degrees s, sw tanzania): New data on vegetation dynamics and climate in central eastern Africa, Rev. Palaeobot. Palynol., 137, 147-162, doi:10.1016/j.revpalbo.2005.06.001, 2005.

Wang, P., Clemens, S., Beaufort, L., Braconnot, P., Ganssen, G., Jian, Z., Kershaw, P., and Sarnthein, M.: Evolution and variability of the Asian monsoon system: State of the art and outstanding issues, Quat. Sci. Rev., 24, 595-629, 2005.

Wang, B. and Ding, Q. H.: Global monsoon: Dominant mode of annual variation in the tropics, Dynam. Atmos. Ocean., 44, 165183, doi:10.1016/j.dynatmoce.2007.05.002, 2008.

Wang, Y. J., Cheng, H., Edwards, R. L., Kong, X. G., Shao, X. H., Chen, S. T., Wu, J. Y., Jiang, X. Y., Wang, X. F., and An, Z. S.: Millennial- and orbital-scale changes in the east Asian monsoon over the past 224,000 years, Nature, 451, 1090-1093, doi:10.1038/nature06692, 2008.

Williams, M., Cook, E., van der Kaars, S., Barrows, T., Shulmeister, J., and Kershaw, P.: Glacial and deglacial climatic patterns in Australia and surrounding regions from 35000 to 10000 years ago reconstructed from terrestrial and near-shore proxy data, Quate. Sci. Rev., 1-22, 2009.

Zebiak, S. E. and Cane, M. A.: A model el niño-southern oscillation, Mon. Weather Rev., 115, 2262-2278, 1987.

Zheng, W., Braconnot, P., Guilyardi, E., Merkel, U., and Yu, Y.: Enso at $6 \mathrm{ka}$ and $21 \mathrm{ka}$ from ocean-atmosphere coupled model simulations, Clim. Dynam., 30, 745-762, doi:10.1007/s00382007-0320-3, 2008.

Ziegler, M., Lourens, L. J., Tuenter, E., Hilgen, F., Reichart, G.-J., and Weber, N.: Precession phasing offset between Indian summer monsoon and Arabian Sea productivity linked to changes in Atlantic overturning circulation, Paleoceanography, 25, PA3213, doi:10.1029/2009PA001884, 2010a.

Ziegler, M., Lourens, L. J., Tuenter, E., and Reichart, G. J.: High Arabian sea productivity conditions during mis 13-odd monsoon event or intensified overturning circulation at the end of the midpleistocene transition?, Clim. Past., 6, 63-76, 2010b. 